\title{
Proton beam therapy in the management of skull base chordomas: Systematic review of indications, outcomes, and implications for neurosurgeons
}

\author{
S.A. Matloob, H.A. Nasir, D. Choi
}

\begin{abstract}
Background

Chordomas are rare tumours affecting the skull base. There is currently no clear consensus on the post-surgical radiation treatments that should be used after maximal tumour resection. However high dose proton beam therapy is an accepted option for post-operative radiotherapy to maximise local control, and in the UK, NHS approval for funding abroad is granted for specific patient criteria.
\end{abstract}

\section{Objectives}

To review the indications and efficacy of proton beam therapy in the management of skull-base chordomas. The primary outcome measure for review was the efficacy of proton-beam therapy in the prevention of local occurrence.

\section{Methods}

A systematic review of English and non-English articles using MEDLINE (1946-present) and EMBASE (1974-present) databases was performed. Additional studies were searched for if referenced in other studies and not available on these databases. Search terms included chordoma or chordomas. The PRISMA guidelines were followed for reporting our findings as a systematic review.

\section{Results}

76 articles met the inclusion and exclusion criteria for this review. Limitations included the lack of documentation of the extent of primary surgery, tumour size, and lack of standardised outcome measures. Proton beam therapy given post operatively in the management of skull base chordomas resulted in better survival rates with less damage to surrounding tissue.

\section{Conclusions}

Proton beam therapy is a recommended treatment modality for post-operative radiation therapy to skull base chordomas. In comparison to other treatment modalities long-term local control and survival is perhaps improved with proton-beam therapy. Further studies are required to directly compare proton-beam therapy to other treatment modalities in selected patients.

\section{Introduction}


Chordomas are uncommon, aggressive primary bone tumours of the axial skeleton. The overall incidence of all chordomas is $0.08-0.5$ cases per 100000 individuals per year, and their incidence at the skull base location is 1 case per 2 million individuals per year. [1,2] They account for $1-4 \%$ of all malignant primary bone tumours. [3]

In human embryos, the notochord forms the axial skeleton which later forms the skull base and vertebrae. [4] Normally, by 1-3 years of age the notochord is replaced by fibrocartilage tissue i.e. the notochord disintegrates. [5] In very few cases there are remnants of the notochord retained within intervertebral discs.[6] These remnants are termed notochord cell rests (NCRs). A chordoma is a cancer that arises from these NCRs.[7] There are three histopathological variants of chordomas: conventional; chondroid; or dedifferentiated. [3,8]

Chordomas can theoretically arise from anywhere along the notochord, however in adults, three main sites have been identified that chordomas arise from, the skull, spine and sacrum. Chordomas arise from these 3 areas with roughly equal distribution. [8] Patients normally present by 4th-6th decade of life in clinic.[2,9] Children and adolescents may also present with these tumours.[10]

Most skull base chordomas arise from the midline clivus[11] and have an infiltrative growth pattern.[12] They present a surgical challenge due to their proximity to neurovascular and bony structures as well as having a high recurrence rate. $[13,14]$. The reported 5 year survival rate for chordomas of the clivus varies widely in the literature from 20-23\% [9] to 95\%[15]. Skull base chordomas and chondrosarcomas often present with impingement of adjacent neural structures in the skull base and cervical spine, and on average are symptomatic for a year before being diagnosed.[16] The most common presenting symptom are visual disturbances such as diplopia. [17] Skull base chordomas can present with epistaxis or intracranial haemorrhage $[18,19]$ and, rarely, with endocrine impairment $[8,20]$. One case reports a giant clival chordoma that presented with pathological laughter[21] although this is extremely rare.

The critical relation of a clival chordoma with the surrounding neural tissue dictates the treatment strategy. The aim of treatment is to avoid damage to the the surrounding brain parenchyma and cranial nerves from damage and to relieve any compression caused by a direct result of the tumour. Surgery is the mainstay of treatment of clival chordomas. External beam radiation is necessary to eradicate any residual tumour. [8] If possible, wide en-bloc resection is important to prevent recurrence. [22-25] This is achievable in the spine and sacrum, however satisfactory excision of such tumours in the skull base is much more difficult given the location and adjacent structures[26-27] as well as the infiltrative nature of these tumours into bone. [3] Local recurrence with surgery alone has been found to be at least $58 \%$ and is associated with significant mortality rates.[28] Numerous surgical approaches have been used and developed with the advances in image guidance and endoscopy, including revision of transsphenoidal and transoral techniques $[8,29,30]$ Subfrontal, transcervical, high anterior cervical retropharyngeal $[8,31,32]$ as well as other midline transfacial (transmandibular and transmaxillary) approaches to these tumours. [1] Lateral approaches include frontotemporal, orbitozygomatic, anterior transpetrosal, pre auricular infratemporal, combined supra and infra-tentorial transtemporal, and extreme lateral transcondylar. [31] The surgical pathway chosen to treat skull base chordomas and chondrosarcomas is normally based on the three subdivisions of the clivus (upper middle and lower). The specific surgical route is also affected by other factors including site, size, extent of local invasion of the tumour (i.e. breaching the dura) and surgical preference [22]. Patients age and co-morbidities may also influence selection of treatment. Surgery is arguably the most important aspect of treatment of chordomas, and partial or subtotal resection leads to an increased chance of recurrence.[8,2225,33]

Chemotherapy has also been proven to be ineffective for these slow growing tumours. Different drugs have been tried in the past to treat these without any positive benefits. Chordomas of the skull base therefore present a challenge in their management due to a number of reasons, and post surgical adjuvant radiotherapy is therefore critical to achieve tumour control. [34] There is good evidence to show that partial or sub-total surgical resection of clival chordomas and 
chondrosarcomas is associated with increased risk of recurrence, [8,22-25] and radiotherapy is considered effective only after maximal surgery. [35]

Different radiation modalities have been used for clival chordoma patients post-surgical resection. Radiotherapy reduces post-operative complications as well decreasing the chance of local recurrence and metastasis. In 1996 particle beam therapy was suggested to be the most effective treatment for cranial base chordomas because to could deliver the necessary dose of radiation to a highly conformed field. [36] Hadrons were introduced to improve the radiobiological effect of radiation and to minimise injury to surrounding neural tissue. They are high-dose protons or charged particles which include carbon ions, helium or neon.

Generally, an ideal radiation dose for chordomas is greater than 70Gy. [3] A more recent study suggested fractionated radiation of roughly 75Gy with once daily fractions of 1.8Gy. [37] The ability to deliver the ideal radiation dose is limited by the tolerance of surrounding structures and the size of the lesion itself. [38] There are currently two schools of thought on radiation dose delivery to clival chordomas. One viewpoint favours sufficient irradiation, if necessary, even at the cost of exceeding the dose threshold of surrounding unaffected tissue. The other viewpoint emphasises adhering to dose thresholds even if that means a part of the tumour will not receive adequate radiation. [37] Whilst both approaches have their advantages each has a clear cost of either tumour control or complications of radiotherapy.

There is currently little guidance on the post operative radiation management of chordomas. High dose proton beam therapy is an accepted and available intervention however access to this treatment modality is often limited. Referral to these services requires specialist approval in the UK. The National Specialised commissioning team for specialised services has provided guidance on the referral for patients to receive proton beam therapy abroad in the management of skull base chordomas and chondrosarcomas. This review highlights the guidance and requirements for proton beam therapy to be approved, and reviews efficacy in comparison to other treatment modalities. An unpublished audit in 2014 by the UK Proton Overseas Programme highlighted a wide variation in imaging and surgical resection, leading to a high rejection rate for funding proton beam therapy, and therefore it is important for neurosurgeons to be aware of current recommendations.

\section{Methods}

A qualitative literature review of English and non-English articles was performed. Methods of the analysis and inclusion criteria were specified in advance and documented in a protocol. Studies included in this systematic review were any articles in which the primary tumour originated from the clivus. Patients of all age groups with a clival tumour were also included. Case series studies of more than 5 patients, Case studies with detailed post-radiation follow up data, case control studies and randomised clinical trials were reviewed. No language, publication date or publication status restrictions were imposed. All studies investigating post-operative radiation techniques for these tumours were reviewed.

Articles looking only at chemotherapy or surgical technique only were excluded. Articles reporting on spinal or sacral chordomas were excluded. Rare presentations or metastases due to clival chordoma, other types of tumour (plasmocytoma and ecchordosis physaliphora) at or near the clivus were also excluded. Articles on whole genome analysis of skull base chordomas, histology and immunohistochemistry studies, surgical steps in cadaveric studies were also excluded. Our primary outcome measure was rate of local recurrence. Studies were identified by searching electronic databases MEDLINE (1946-present) and EMBASE (1974-present) databases was performed. Additional studies were searched for if referenced in other studies and not available on these databases. The last search was performed on 12th April 2015.

We used the following search terms: chordoma OR chordomas AND clivus OR clival; chordoma(s) AND clivus AND radiation OR radiotherapy. Eligibility assessment was performed independently in an unblinded standardised manner by 2 reviewers. Disagreements between reviewers were 
resolved by consensus. There were no disagreements in the cases that were included or excluded. A data extraction sheet was developed. This was tested on ten randomly selected studies and refined accordingly. One review author extracted the data and the second author checked and analysed the data. Any disagreements were discussed between the two authors and if no consensus could be reached, the third author would decide. The information extracted from each paper was the number of cases, the radiotherapy treatment received and dose, the follow up, survival, time to recurrence, relative risk of mortality with different radiation modalities. To explore variability in study results we specified the following hypothesis before the analysis. We hypothesised that effect size may differ according to the methodological quality of the studies. The primary outcome measure was the relative risk of mortality reduction using different radiotherapy modalities.

\section{Results}

The search of MEDLINE and EMBASE identified 6408 articles relating to chordoma or chordomas, 4077 articles relating to clivus or clival and 770653 articles relating to radiotherapy. 258 articles were identified when these three search items were combined. These 258 articles were read, inclusion and exclusion criteria were applied and duplicates removed. This resulted in 12 articles investigating radiation therapy in the management of skull base chordomas.

Six studies reported both survival and local control with the use of proton therapy. Table 1 summarises these studies.

Table 1: Survival and local control percentages of patients with skull base chordomas treated with different forms of post operative radiation therapy.

There is a conflict in the predominance of base of skull chordomas by gender. One group reported a female predominance [2] whereas another more recent study reported a slight male predominance. [37] Four case series' of a total of 99 patients treated with stereotactic radiosurgery (gamma knife) were studied. In 1970 Pearlman et al. were the first who described a link between 


\begin{tabular}{|c|c|c|c|c|c|c|}
\hline Study & $\begin{array}{l}\text { Number of } \\
\text { patients }\end{array}$ & Radiation & $\begin{array}{l}\% \text { Local } \\
\text { control }\end{array}$ & $\%$ survival & $\begin{array}{l}\text { Length of } \\
\text { Follow up }\end{array}$ & Radiation dosage \\
\hline $\begin{array}{l}\text { Hug EB et.al. } 1999 \\
\text { Proton radiation therapy for } \\
\text { chordomas and } \\
\text { chondrosarcomas of the skull } \\
\text { base [37] }\end{array}$ & 33 & $\begin{array}{l}\text { Synchroton; } \\
\text { Passive scattering; } \\
\text { energy } 155-200 \mathrm{MeV}\end{array}$ & $\begin{array}{l}3 \text { year } 67 \% \\
5 \text {-year } 59 \%\end{array}$ & $\begin{array}{l}3 \text {-year } 87 \% \\
5 \text { year } 79 \%\end{array}$ & $\begin{array}{l}\text { 13-92months } \\
\text { (mean 40) }\end{array}$ & $\begin{array}{l}\text { 50.4-78.6Gy (1.8- } \\
\text { 2Gy/fraction) }\end{array}$ \\
\hline $\begin{array}{l}\text { Munzenrider JE et.al. } 1999 \\
\text { Proton therapy for tumours of } \\
\text { the skull base [38] }\end{array}$ & 169 & $\begin{array}{l}\text { Cyclotron; } \\
\text { Passive scattering; } \\
\text { Energy } 160 \mathrm{MeV}\end{array}$ & $\begin{array}{l}5 \text { year } 73 \% \\
10 \text { year } 54 \%\end{array}$ & $\begin{array}{l}5 \text { year } 80 \% \\
10 \text { year } 54 \%\end{array}$ & $\begin{array}{l}1-254 \text { months } \\
\text { (median } 41 \\
\text { months) }\end{array}$ & 66-83 Gy \\
\hline $\begin{array}{l}\text { Hug EB et.al. } 2002 \\
\text { Proton radiotherapy in the } \\
\text { management of paediatric } \\
\text { base of skull tumours [39] }\end{array}$ & 10 & $\begin{array}{l}\text { Cyclotron; } \\
\text { Passive scattering; } \\
\text { energy } 160 \mathrm{MeV} \\
\text { Synchotron; } \\
\text { passive scattering; } \\
\text { energy } 155-200 \mathrm{MeV}\end{array}$ & $60 \%$ & $60 \%$ & & \\
\hline $\begin{array}{l}\text { Igaki } \mathrm{H} \text { et.al. } 2004 \\
\text { Clinical results of proton } \\
\text { beam therapy for skull base } \\
\text { chordoma [40] }\end{array}$ & 13 & $\begin{array}{l}\text { Synchroton; } \\
\text { Passive scattering; } \\
\text { energy } 250 \mathrm{MeV}\end{array}$ & $\begin{array}{l}3 \text { year } 67.1 \% \\
5 \text {-year } 46 \%\end{array}$ & $\begin{array}{l}3-\text { year } 84.6 \% \\
5 \text { year } 66.7 \%\end{array}$ & & \\
\hline $\begin{array}{l}\text { Weber DC et.al } 2005 \\
\text { Results of spot-scanning } \\
\text { proton radiation therapy for } \\
\text { chordoma and } \\
\text { chondrosarcoma of the skull } \\
\text { base: The Paul Scherrer } \\
\text { Institut experience [41] }\end{array}$ & 18 & $\begin{array}{l}\text { Cyclotron; } \\
\text { spot scanning; } \\
\text { energy } 510 \mathrm{MeV}\end{array}$ & 3 year $87.5 \%$ & 3 year $93.8 \%$ & $\begin{array}{l}\text { 6-68 months } \\
\text { (mean } 29 \text { months) }\end{array}$ & 68 CGE mean \\
\hline $\begin{array}{l}\text { Noel G et.al. } 2005 \\
\text { Chordomas of the base of the } \\
\text { skull and upper cervical spine. } \\
\text { One hundred patients } \\
\text { irradiated by a 3D conformal } \\
\text { technique combining photon } \\
\text { and proton beams [42] }\end{array}$ & 100 & $\begin{array}{l}\text { Cyclosynchroton; } \\
\text { Passive scattering; } \\
\text { energy } 201 \mathrm{MeV}\end{array}$ & $\begin{array}{l}2 \text { year } 86.3 \% \\
4 \text { year } 53.8 \%\end{array}$ & $\begin{array}{l}2 \text { year } 94.3 \% \\
5 \text { year } 80.5 \%\end{array}$ & median 31 months & 67Gy \\
\hline $\begin{array}{l}\text { Benk V et.al. } 1995 \text { Base of } \\
\text { Skull and cervical spine } \\
\text { chordomas in children treated } \\
\text { by high dose irradiation }\end{array}$ & 18 & 160MeV Cyclotron & 5 yr $78 \%$ & 5 yr $68 \%$ & mean 72 months & 69 CGE, 1.8CGE/fraction \\
\hline $\begin{array}{l}\text { Debus } \mathrm{J} \text { et al. } 1997 \text { Brainstem } \\
\text { tolerance to conformal } \\
\text { radiotherapy of skull base } \\
\text { tumours }\end{array}$ & 367 & 160MeV Cyclotron & 10 yr $84 \%$ & $\begin{array}{l}5 \text { yr } 94 \% 10 y r \\
86 \%\end{array}$ & $\begin{array}{l}6 \text { months }-21.4 \\
\text { years (mean } \\
42.5 \text { months) }\end{array}$ & 67.8 CGE \\
\hline $\begin{array}{l}\text { Habrand JL et al. } 1988 \\
\text { Protontherapy in pediatric } \\
\text { skull base and cervical canal } \\
\text { chodromas. Iong term } \\
\text { outcome of the orsay series }\end{array}$ & 34 & 160MeV Cyclotron & & & $\begin{array}{l}\text { 30-68months } \\
\text { (mean 52) }\end{array}$ & 66.6-74.4CGE \\
\hline $\begin{array}{l}\text { Wei HJ. et al. Endoscopic } \\
\text { resection of chordomas in } \\
\text { different clival regions } 2009\end{array}$ & 9 & IMRT & $100 \%$ & $100 \%$ & 6 months -3 years & not stated \\
\hline $\begin{array}{l}\text { Ito E. et.al. } 2009 \text { Long-term } \\
\text { control of clival chordoma with } \\
\text { initial aggressive surgical } \\
\text { resection and gamma knife } \\
\text { radiosurgery for recurrence }\end{array}$ & $\begin{array}{l}13 \text { (4 initial, } 10 \\
\text { on recurrence) }\end{array}$ & Gamma Knife & $\begin{array}{l}75 \% \text { on initial } \\
\text { treatment }\end{array}$ & $\begin{array}{l}2 \text { year }-77.9 \% \\
5 \text { year- } 47.9 \% \\
\text { (progression free } \\
\text { Survival) }\end{array}$ & mean 71.2 months & \\
\hline $\begin{array}{l}\text { Ahmed R. et.al. Disease } \\
\text { outcomes for skull base and } \\
\text { spinal chordomas: a single } \\
\text { centre experience. } 2015\end{array}$ & 30 & HS-FSRT & $70 \%$ & & 6.3 years & \\
\hline
\end{tabular}

the dose and response to treatment of photon radiation therapy in chordomas. [45] The data suggests a 5-year local control of $55.7 \%$ based on the average of three studies. The overall 5 year survival was $74 \%$. [36-48]

There are several limitations to this review. Different extents of surgery were not always documented (complete or incomplete excision, for example), different sizes of presenting tumours were often grouped together, and primary or revision surgeries were not necessarily specified. This heterogeneity of study variables, patient and disease characteristics, and often multiple different radiotherapy modalities in the surgical series, make direct comparisons unwise.

Different radiation modalities have been used for chordomas, including stereotactic radiosurgery, proton beam and other heavy charged particles. Stereotactic radiosurgery damages the DNA of 
tumour cells, and aims to prevent tumour cell division. Sources of radiation include Cobalt-60 source for Gamma-knife, whereas linear accelerators are used to provide radiation in Cyber-knife therapy.

Proton therapy is, generally, used in cases where conventional radiotherapy is insufficient to control local tumour progression and whenever critical normal tissue is in close proximity to the tumour. [49] In proton therapy multiple beams are designed based on the target volume to deliver effective radiation dose without damage to surrounding tissue in the skull base, 3 dimensional treatment planning and proton radiation therapy is therefore the most effective method to deliver high dose radiation to a lesion following surgical resection. [50]

Among the advantages of protons is the sudden dose decline beyond the target. [3] This is because of the characteristic Bragg Peak of proton beam radiation. [36] Another benefit is that high dose protons or charged particles allow higher doses of radiation to be delivered to the target volume. This reduces the radiation injury and improves radiobiological effect. [51]

There is significant heterogeneity in the literature on chordomas and their management. This is especially true in the role adjuvant radiotherapy plays in relation to extent of surgical resection. $[52,53]$ In addition to proton beam therapy, gamma knife, charged heavy particle therapy and intensity modulated radiation therapy (IMRT) have also been used. There remains no evidence of clinical superiority of one radiotherapy modality over another.

Currently patients in England requiring high energy proton beam therapy must be referred to a Proton Clinical reference panel (PCRP) for approval for consideration of having proton beam therapy abroad. [54] The Department of Health are also taking forward a strategy to commission high energy proton therapy in England, and this service is expected to be available within the next few years. Treatment centres abroad have placed constraints on whom they will accept through the NHS funded route based on local criteria of suitability. Patients are referred to the PCRP by the clinical oncologist who reviewed the patient locally.

There is good evidence that maximal safe surgical resection is necessary to provide the best possible prognosis, and indeed, treatment centres will not accept cases of skull base chordomas if pre and post op MRI imaging is not available, or it is considered that insufficient surgery has been performed. A number of general restrictions also exist for referral to proton beam therapy. [figure 1]

Figure 1: Recommendations for Proton Beam Therapy

Key principles to consider when applying for Proton beam therapy funding in the UK.

Treatment should be given with curative intent

Patients will have good performance status (WHO 0-1 performance status) [50]

No other diagnoses that will limit 5-year survival or make prolonged period abroad difficult to manage

There should be no metastatic disease

Re-treatment cases will not be accepted

Patient weight at time of referral should not exceed $150 \mathrm{~kg}$

Maximal safe surgery has been performed 
Key principles to consider when applying for Proton beam therapy funding in the UK.

Adequate clearance from eloquent nervous structures, eg. $3 \mathrm{~mm}$ clearance from the brainstem, and $5 \mathrm{~mm}$ clearance from the optic chiasm.

Avoid metal implants at the craniocervical junction unless unstable, and if necessary, avoid screws or cross-bars at the level of the tumour resection.

At present proton therapy seems to be more promising in achieving better long term local control and overall survival. This is shown by better overall percentages.

\section{Implications for surgery}

Post-operative imaging is mandatory, to decide residual volume of tumour, and clearance from eloquent structures. If insufficient clearance has been achieved, then further surgery should be considered prior to referral for proton beam therapy. Complete resection is the goal, within the constraints of safety and minimising complications. However, surgery inevitably carries some risk, and this needs to be weighed by the surgeon, oncologist and patient, on a case-by-case basis. Since chordomas are rare tumours and the surgery itself is challenging, operations should be performed in specialised neurosurgical centres with sufficient volume to maintain surgical expertise, access to radiological and other supporting services, within the context of multidisciplinary team discussion. Specialist centres should have access to the full range of technical approaches required (endoscopic, anterior, lateral and posterior skull base approaches), All centres should audit their quality of surgery, complication rates, radiological outcomes, and patient survival, which allows service monitoring and improvement. This may entail fewer surgical centres in the UK performing greater numbers of operations in the future, with the goal of improving patient benefit.

\section{Conclusions}

In the UK, proton therapy is felt to be the most effective radiation modality in the management of post-resection skull base chordomas. Local control and survival are likely to be improved when compared to other radiation modalities. Further studies must be conducted to gain a better understanding of the indications, shortcomings and areas of improvement for this technique, and currently there is no level 1 evidence comparing different post-operative radiotherapy techniques. Although proton beam therapy for chordomas is to be recommended, other modalities such as stereotactic radiosurgery, intensity modulated radiotherapy, or other heavy particles, continue to have a role in treatment. 


\section{References}

1. Crockard HA, Steel T, Plowman N, Singh A, Crossman J, Revesz T, Holton JL, Cheeseman A. 2001. A multidisciplinary team approach to skull base chordomas. J Neurosurg Aug;95(2):17583.

2. McMaster ML, Goldstein AM, Bromley CM, Ishibe N, Parry DM: Chordomas: incidence and survival patterns in the United States, 1973-1995. 2001. Cancer Causes Control 12:1-11

3. Amichetti M, Cianchetti M, Amelio D, Enrici RM, Minniti G. 2009. Proton therapy in chordoma of the base of the skull: a systematic review. Neurosurg Rev. Oct;32(4):403-16

4. Aydin AL, Sasani M, Oktenoglu T, Solaroglu I, Ozer AF. 2013. A case of chordoma invading multiple neuroaxial bones: report of ten years follow up. Turk Neurosurg 23(4);551-6

5. Yamaguchi T, Yamato M, Saotome K. 2002. First histologically confirmed case of a classic chordoma arising in a precursor benign notochordal lesion: differential diagnosis of benign and malignant notochordal lesions. Skeletal Radiol Jul;31(7):413-8

6. Shen J, Shi Q, Lu J, Wang DL, Zou TM, Yang HL, Zhu GQ. 2013. Histological study of chordoma origin from fetal notochord cell rests. Spine Dec 1;38(25):2165-70

7. Watkins L, Khudados ES, Kaleoglu M, Revesz T, Sacares P, Crockard HA. 1993. Skull base chordomas: A review of 38 patients 1958-88. Br J Neurosurg 7:241-248.

8. Walcott BP, Nahed BV, Mohyeldin A, Coumans JV, Kahle KT, Ferreira MJ. 2012. Chordoma: current concepts, management, and future directions. Lancet Oncol Feb;13(2):e69-76

9. Harbour JW, Lawton MT, Criscuolo GR, Holliday MJ, Mattox DE, Long DM. 1991. Clivus chordoma: a report of 12 recent cases and review of the literature;1(4):200-6

10. Tsai EC, Santoreneos S, Rutka JT. 2002. Tumours of the skull base in children: review of tumour types and management strategies. Neurosurg Focus May 15;12(5)

11. Noel G, Habrand JL, Jauffret E, de Crevoisier R, Dederke S, Mammar H, Haie-Meder C, Pontvert D, Hasboun D, Ferrand R, Boisserie G, Beaudre A, Gaboriaud G, Guedea F, Petriz L, Mazeron JJ. 2003. Radiation therapy for chordoma and chondrosarcoma of the skull base and the cervical spine. Prognostic factors and patterns of failure. Strahlenther Onkol. Apr;179(4):241-8

12. Stuer C, Schramm J, Schaller C. 2006. Skull base chordomas: management and results. Neuro Med Chir Mar;46(3):118-24

13. Al-Mefty O, Borba LA. 1997. Skull base chordomas: a management challenge. J Neurosurg 86:182-189

14. Colli B, Al-Mefty O. 2001. Chordomas of the craniocervical junction: follow up review and prognostic factors. J Neurosurg 95:933-943

15. Debus J, Hug EB, Liebsch NJ, O'Farrel D, Finkelstein D, Efird J, Munzenrider JE. 1997. Brainstem tolerance to conformal radiotherapy of skull base tumours. Int J Radiat Oncol Biol Phys. Dec 1;39(5):967-75

16. Menezes AH. 2014. Clival and craniovertebral junction chordomas. World Neurosurg. MayJun;81(5-6):690-2

17. Volpe NJ, Liebsch NJ, Munzenrider JE, Lessell S. 1993. Neuro-opthalmologic findings in chordoma and chondrosarcoma of the skull base. Am J Opthalmol 115:97-104

18. Kitai R, Yoshida K, Kobota T, Sato K, Handa Y, Kasahara K, Nakajima H. 2005. Clival chordoma manifesting as nasal bleeding. A case report. Neuroradiology May;47(5):368-71

19. Levi AD, Kucharczyk W, Lang AP, Schultz H. 1991. Clival chordoma presenting with acute brain stem hemorrhage. Can J Neurol Sci. Nov;18(4):515-8

20. Stark AM, Mehdorn HM. 2003. Images in clinical medicine. Chondroid clival chordoma. N Engl J Med Sep 4;349(10)

21. Gripp DA, do Souto AA, Gonsales D, Christiani Mde M, Nogueira J, Lopes HF, Torres YC. 2014. Giant clival chordoma causing pathological laughter. Surg Neurol Int. Feb 17;5:18

22. Tzortzidis F, Elahi F, Wright D, Natarajan SK, Sekhar LN. 2006 Patient outcome at long-term follow-up after aggressive microsurgical resection of cranial base chordomas. Neurosurgery Aug;59(2):230-7

23. Osaka S, Kodoh O, Sugita H, Osaka E, Yoshida Y, Ryu J. 2006. Clinical significance of a wide excision policy for sacrococcygeal chordoma. J Cancer Res Clin Oncol. Apr;132(4):213-8.

24. Bjornsson J, Wold LE, Ebersold MJ, Laws ER. 1993. Chordoma of the mobile spine. A clinicopathologic analysis of 40 patients. Cancer. Feb1;71(3):735-40 
25. Fuchs B, Dickey ID, Yaszemski MJ, Inwards CY, Sim FH. 2005. Operative management of sacral chordoma. J Bone Joint Surg Am. Oct;87(10):2211-6

26. Castro JR, Linstadt DE, Bahary JP, Petti PL, Daftari I, Collier JM, Gutin PH, Gauger G, Phillips TL. 1994. Experience in charged particle irradiation of tumours of the skull base: 1977-1992. Int J Radiat Oncol Biol Phys Jul 1;29(4):647-55

27. Benk V, Liebsch NJ, Munzenrider JE, Efird J, McManus P, Suit H. 1995. Base of skill and cervical spine chordomas in children treated by high-dose irradiation. Int J Radiat Oncol Biol Phys Feb 1;31(3):577-81

28. Pamir MN, Kilic T, Ture U, Ozek MM. 2004. Multimodality management of 26 skull-base chordomas with 4-year mean follow up: experience at a single institution. Act Neurochir 146(4):343-354

29. Jho HD, Carrau RL, McLaughlin MR, Somaza SC. 1997. Endoscopic transsphenoidal resection of a large clival chordoma in the posterior fossa. Acta Neurochir 139:343-348.

30. Rudnik A, Zawadzki T, Wojtacha M, Bazowski P, Gamrot J, Galuszka-Ignasiak B, Duda I. 2005. Endoscopic transnasal transsphenoidal treatment of pathology of the sellar region. Minim Invasive Neurosurg. Apr;48(2):101-7.

31. Sen C, Triana AI, Berglind N, Godbold J, Shrivastava RK. 2010. Clival Chordomas: clinical management, results and complications in 71 patients. J Neurosurg 2010 Nov;113(5):1059-71

32. Delgado TE, Garrido E, Harwick RD. 1981. Labiomandibular, transoral approach to chordomas in the clivus and upper cervical spine. Neurosurgery Jun;8(6):675-9

33. Choi D, Melcher R, Harms J, Crockard A. 2010. Outcome of 132 operations in 97 patients with chordomas of the craniocervical junction and upper cervical spine. Neurosurgery 2010 Jan;66(1):59-65

34. Deraniyagala RL, Yeung D, Mendenhall WM, Zuofeng L, Morris CG, Mendenhall NP, Okunieff P, Malyapa RS. 2014. Proton beam therapy for skull base chordomas: An outcome study from the University of Florida Proton Therapy Institute. J Neurol Surg B Skull Base. Feb;75(1):53-7

35. Boriani S, Chevalley F, Weinstein JN, Biagini R, Campanacci L, De lure F, Piccill P. 1996. Chordoma of the spine above the sacrum. Treatment and outcome in 21 cases. Spine. Jul $1 ; 21(13): 1569-77$

36. Catton C, O'Sullivan B, Bell R, Laperriere N, Cummings B, Fornasier V, Wunder J. 1996. Chordoma: long-term follow-up after radical photon irradiation.

37. Fernandez-Miranda JC, Gardner PA, Snyderman CH, Devaney KO, Mendenhall WM, Suarez C, Rinaldo A, Ferlito A. 2014. Clival chordomas: A pathological, surgical, and radiotherapeutic review.

38. Chetiyawardana AD. 1984. Chordoma: results of treatment. Clin Radiol. Mar;35(2):159-61

39. Hug EB, Loredo LN, Slater JD, DeVries A, Grove RI, Schaefer RA, Rosenberg AE, Slater JM. 1999. Proton radiation therapy for chordomas and chondrosarcomas of the skull base. $J$ Neurosurg. Sep;91(3):432-9.

40. Munzenrider JE, Liebsch NJ. 1999. Proton therapy for tumours of the skull base. Strahlenther Onkol. Jun;175 Suppl2:57-63. Review.

41. Hug EB, Sweeney RA, Nurre PM, Holloway KC, Slater JD, Munzenrider JE. 2002. Int J Radiat Oncol Biol Phys Mar 15;52(4):1017-24

42. Igaki H, Tokuuye K, Okumura T, Sugahara S, Kagei K, Hata M, Ohara K, Hashimoto T, Tsuboi K, Takano S, Matsumara A, Akine Y. 2004. Clinical results of proton beam therapy for skull base chordoma. Int J Radiat Oncol Biol Phys. Nov 15;60(4):1120-6

43. Weber DC, Rutz HP, Pedroni E, Bolsi A, Timmermann B, Verwey J, Lomax AJ, Goitein G. 2005. Results of spot-scannin proton radiation therapy for chordoma and chondrosarcoma os the skull base: the Paul Scherrer Institut experience. Int J Radiat Oncol Biol Phys Oct $1 ; 63(2): 410-9$

44. Noel G, Fuevret L, Calugaru V, Dhermain F, Mammar H, Haie-Meder C, Ponvert D, Hasboun D, Ferrand R, Nauraye C, Boisserie G, Beaudre A, Gaboriaud G, Mazal A, Habrand JL, Mazeron JJ. 2005. Chordomas of the base of the skull and upper cervical spine. One hundred patients irradiated by a 3D conformal technique combining photon and proton beams. Acta Oncol 44(7):700-8

45. Pearlman AW, Friedman M. 1970. Radical radiation therapy of chordoma. Am J Roentgenol Radium Ther Nucl Med. Feb;108(2):332-41 
46. Crockard A, Macaulay E, Plowman PN. 1999. Stereotactic radiosurgery. VI. Posterior displacement of the brainstem facilitates safer high dose radiosurgery for clival chordoma. $\mathrm{Br} J$ Neurosurg Feb;13(1):65-70

47. Hasegawa T, Ishii D, Kida Y, Yoshimoto M, Koike J, lizuka H. 2007. Gamma Knife surgery for skull base chordomas and chondrosarcomas. J Neurosurg. Oct;107(4):752-7

48. Krishnan S, Foote RL, Brown PD, Pollock BE, Link MJ, Garces YI. 2005. Radiosurgery for cranial base chordomas and chondrosarcomas

49. Levin WP, Kooy H, Loeffler JS, DeLaney TF. 2005. Proton beam therapy. Br J Cancer Oct 17;93(8):849-54

50. Austin-Seymour M, Menzenrider J, Goitein M, Verhey L, Urie M, Gentry R, Birnbaum S, Ruotolo D, McManus P, Skates S, Ojemann RG, Rosenberg A, Schiller A, Koehler BA, Suit HD. 1989. Fractionated proton radiation therapy of chordoma and low-grade chondrosarcoma of the base of the skull. J Neurosurg. Jan;70(1):13-7.

51. Oken MM, Creech RH, Tormey DC, Horton J, Davis TE, McFadden ET, Carbone PP. 1982. Toxicity and Response Criteria of the Easter Cooperative Oncology Group. Am J Clin Oncol 5;649-655.

52. Di Maio S, Yip S, Al Zhrani GA, Alotaibi F, Al Turki A, Kong E, Rostomily RC. 2015 Novel targeted therapies in chordoma: An update. Ther Clin Risk Manag May 26;11:873-83

53. Jian BJ, Bloch OG, Yang I, Han SJ, Aranda D, Parsa AT. A Comprehensive analysis of intracranial chordoma and survival: A systematic review. 2011. Br J Neurosurg. 25(4):446-53

54. http://www.dh.gov.uk/en/Publicationsandstatistics/Publications/PublicationsPolicyAndGuidance IDH 123371 Accessed 13th August 2015. 